\title{
EVALUATION OF THE RELATIONSHIP OF MPV, RDW AND PVI PARAMETERS WITH DISEASE SEVERITY IN COVID-19 PATIENTS
}

\author{
Dilek Atik and Hasan Burak Kaya \\ Department of Emergency Medicine, Yozgat Bozok University, Yozgat, Turkey
}

\begin{abstract}
SUMMARY - Coronavirus was first detected in three severe pneumonia cases in Wuhan, China, in December 2019. Studies on red cell distribution width (RDW-CV) and mean platelet volume (MPV) laboratory parameters, which can be examined in complete blood count in COVID-19 patients, are still very limited. However, to the best of our knowledge, there are no studies examining the relationship between platelet volume index (PVI) and disease severity in COVID-19 patients, which was evaluated in this study. The aim of this study was to evaluate the relationship of disease severity in COVID-19 patients with their MPV, RDW, and PVI parameters. The study included 92 COVID-19 patients as a study group and 84 healthy individuals as control group. All laboratory data and radiological images were scanned retrospectively from patient files and hospital information system. Evaluation of the RDW-CV and MPV blood parameters, and PVI measured in COVID-19 patients yielded statistically significant differences according to the disease severity. We suggest that RDW-CV and PVI, evaluated within the scope of the study, may be the parameters that should be considered in the early diagnosis of the disease, from the initial stages of COVID-19. In addition, we think that the RDW-CV and MPV laboratory parameters, as well as PVI, which all are simple, inexpensive and widely used hematologic tests, can be used as important biomarkers in determining COVID-19 severity and mortality.
\end{abstract}

Key words: COVID-19; Disease severity; Mean platelet volume; Red cell distribution width; Platelet volume index

\section{Introduction}

Coronavirus was first detected in three severe pneumonia cases in Wuhan, China, in December 2019. Besides its flu-like symptoms, the severe acute respiratory syndrome coronavirus 2 (SARS-CoV-2) causes multiorgan failure and death with its rapid progression. This very contagious disease was accepted as a worldwide pandemic by the World Health Organization as of February 20201,2. Coronavirus (COV-

Correspondence to: Assist. Prof. Dilek Atik, PhD, Yozgat Bozok Universitesi, Acil Tip Ana Bilim Dali, Capanoglu Mah., Cemil Cicek Cad., Bozok Universitesi Erdogan Akdag Yerleskesi Ataturk Yolu 7.km, 66100 Yozgat Merkez/Yozgat, Turkey

E-mail: dr.dilekgok82@hotmail.com

Received October 13, 2020, accepted February 15, 2021
ID-19), which was first thought to be transmitted from bat, belongs to the betacoronavirus family, which is a subtype of the SARS group viruses. To exert its effect, coronavirus binds to the angiotensin-converting enzyme-2 receptor on the cell surface ${ }^{3}$.

Pneumonia in COVID-19 patients is thought to be associated with neutrophil infiltration in the lungs and increased serum proinflammatory cytokines and chemokines, together with a high onset viral load ${ }^{4}$. Some studies have reported changes in hematologic parameters during acute infection caused by SARSCoV-2 $2^{5-11}$.

Red cell distribution width (RDW), mean platelet volume (MPV), and platelets are some of the hematologic parameters. RDW is a routinely reported marker of complete blood count (CBC) and represents a mea- 
sure of red blood cell size heterogeneity ${ }^{12}$. The RDW laboratory parameter has been associated with many diseases such as social pneumonia, hypoxemia, and pulmonary embolism ${ }^{13-15}$.

Platelets are one of the hematologic parameters as essential cells for host defense and repair, in addition to being known as the main effectors of hemostasis ${ }^{16}$. Platelets contribute to a variety of immune responses and a range of inflammatory disorders in the lungs and other organs ${ }^{17,18}$. Studies have reported that platelet count is a biomarker which is independently associated with disease severity and mortality risk in critically ill patients in intensive care unit (ICU) ${ }^{19-21}$. Recent studies have reported that platelet parameters may contribute to the diagnosis of diseases and have a prognostic value in some pathologies ${ }^{22}$. The MPV laboratory parameter is a promising marker that may indicate systemic inflammation ${ }^{23,24}$. The literature emphasizes that the MPV blood parameter can be useful in the diagnosis of inflammatory diseases such as pneumonia, as well as in the prognosis evaluation in chronic diseases such as tumors, diabetes, and coronary heart disease $\mathrm{e}^{25-27}$.

Since the COVID-19 pandemic is a recent situation, treatment and vaccination studies are still ongoing. Treatment methods are changing every day due to the development of new unknown symptoms and organ failure, and the literature is renewed in the light of new studies. Preventing progression of the disease with early diagnosis and effective treatment strategies of COVID-19, and reducing mortality is one of the main goals. Studies on RDW-CV and MPV laboratory parameters, which can be examined in $\mathrm{CBC}$ in COVID-19 patients, are still very limited. Platelet volume index (PVI; MPV/platelet ratio) can contribute to clarifying the activities of platelets that are involved in inflammation ${ }^{28}$.

In some previous studies, it has been reported that PVI is one of the thromboembolism markers, and may be an important marker in evaluating the risk of cardiovascular disease in diabetes and hypertension ${ }^{29,30}$. However, to the best of our knowledge, there are no studies examining the relationship between PVI and disease severity in COVID-19 patients, and it was investigated in the present study.

In this study, we aimed to evaluate the relationship of disease severity in COVID-19 patients with their MPV, RDW and PVI parameters.

\section{Subjects and Methods}

\section{Study participants}

The study was conducted between March 15, 2020 and June 20,2020 as a retrospective single-center study. The study included 92 COVID-19 patients as a patient group and 84 healthy individuals as control group. The study was approved by the Ethics Committee of the Yozgat Bozok University as of July 22, 2020, decision no. 2020-06-147. The study was carried out in accordance with the Helsinki Declaration. The patient group consisted of COVID-19 patients admitted to the Emergency Department with various symptoms and complaints, whose diagnosis was confirmed by realtime reverse transcription-polymerase chain reaction (rRT-PCR). The healthy control group consisted of people who presented to the hospital for general examination. COVID-19 patients were subdivided according to the diagnostic criteria of the COVID-19 (2019-nCoV Disease) Guide published by the Turkish Ministry of Health and updated with recent developments ${ }^{31}$. Accordingly, patient groups were defined as group 1 with mild severity, group 2 with medium severity, group 3 with high severity, and group 4 as critical cases. Group 1 patients had mild clinical symptoms and group 2 patients had fever, respiratory symptoms and radiological findings of pneumonia. Patients with any of the symptoms of shortness of breath, respiratory rate $(\mathrm{RR}) \geq 30 / \mathrm{min}$, oxygen saturation value $\leq 93 \%$ at rest, and $(\mathrm{PaO} 2 / \mathrm{FiO} 2) \leq 300 \mathrm{~mm} \mathrm{Hg}$ were included in group 3. Patients with respiratory failure requiring mechanical ventilation, clinical picture of shock or organ failure were included in group 4 . In order to facilitate the clinicians' planning of COVID-19 patient follow up, in addition to the patient group diagnostic guide, it was also planned to evaluate COVID-19 patients in two groups where one group included patients with serious to critical severity and the other group included patients with mild to moderate severity.

\section{Data collection}

Patients included in the study were analyzed for age, gender, hospital admission symptoms, chronic disease history, clinical outcomes, survival, and CBC parameters determined on a Sysmex XN-1000 hematologic analyzer (Sysmex Co., Japan). Patient serum biochemistry was performed on a Roche Cobas C501 
chemistry analyzer (Roche Diagnostics, Mannheim, Germany). All laboratory data and radiological images were scanned retrospectively from patient files and hospital information system. Data on patient clinical outcomes and survival were obtained from the hospital information system. PVI was calculated as PVI=MPV value (f)/Plt per $1000 \times 100^{32}$, and then recorded.

\section{Statistical analysis}

All data were statistically analyzed with the SPSS version 20.0 for Windows. Kolmogorov-Smirnov test and skewness-kurtosis method were used to evaluate normal distribution of all variables. Additionally, normal data distribution was evaluated by a histogram. The $\chi^{2}$-test and Fisher exact test were used to compare proportions of categorical variables. Descriptive statistics was used to analyze patient demographic data. Numerical values were expressed as mean \pm standard deviation and minimum-maximum values. Student's t-test was used for parametric variables within the scope of clinical research. Kruskal-Wallis $H$ test and Mann-Whitney U test were used for statistical evaluation of non-parametric variables depending on their categorical (nominal or ordinal) and numerical independence status. Spearman rank correlation method was used for correlation of nonparametric data. According to clinical results of COVID-19 patients, RDW-CV, MPV and PVI values were evaluated with the receiver-operating characteristic curve (ROC). On ROC analysis, parameters with the area under the curve (AUC) value below 0.6 and without statistical significance $(p>0.05)$ were excluded. The level of statistical significance was set at $\mathrm{p}<0.05$.

\section{Results}

Between March 15, 2020 and June 20, 2020, 230 patients were admitted to the Emergency Department due to upper and lower respiratory tract infections. Of these, 92 patients had positive PCR test result, whereas 128 patients were diagnosed with other upper and lower respiratory tract infections and were excluded from the study. In our study, data on 92 patients admitted to the hospital with confirmed COVID-19 diagnosis were analyzed (Table 1 ). There was no significant difference in median age between 92 confirmed CO-
VID-19 patients and 84 controls ( $>0.05)$. In the patient group, there were 47 (51.1\%) male and 45 (48.9\%) female patients. In the control group, there were 43 male and 41 female subjects, yielding no significant between-group difference in gender composition $(\mathrm{p}>0.05)$.

\section{Demographic and clinical characteristics of COVID-19 patients and healthy control group}

Demographic characteristics and clinical findings of the 92 COVID-19 patients and 84 healthy control subjects are summarized in Table 1 . Median age of COVID-19 patients and control subjects was 61.3 and 58.5 years, with no significant difference between the groups $(p<0.05)$. Although median age of the COVID-19 patient groups was higher in critically ill patients, there was no statistically significant difference between the groups ( $p>0.05)$. Similarly, even though there was no statistically significant difference in gender distribution by clinical groups in the COVID-19 patient group, the proportion of male patients was higher than of female patients, especially in severe COVID-19 cases. Fever, dyspnea and cough were the most common clinical symptoms in study patients, as well as in COVID-19 patients with moderate disease severity. There was a statistically significant difference in the symptoms of dyspnea and joint pain $(\mathrm{p}<0.05)$ between the groups. Comorbidities were recorded in $54.9 \%(n=51)$ of COVID-19 patients. Table 1 shows comorbidity distribution in the patient and control groups. Accordingly, disease severity in patients with chronic obstructive pulmonary disease (COPD) and coronary artery disease comorbidities was higher in the severe and critical groups, and this difference was significantly higher as compared with other patient groups (mild and moderate) $(\mathrm{p}<0.05)$.

\section{Laboratory characteristics of COVID-19 patients and healthy control group}

Differences in laboratory findings between COVID-19 patients and control group are shown in Table 2. Patient group had higher leukocyte levels $(\mathrm{p}<0.05)$ and lower total protein levels $(\mathrm{p}<0.05)$ than control group. Besides, hypoalbuminemia (serum albumin $\leq 40 \mathrm{~g} / \mathrm{L}$ ) and lymphopenia (lymphocyte count $\leq 1.1 \times 10^{9} / \mathrm{L}$ ) were observed in the COVID-19 patient 
Table 1. Baseline clinical characteristics of COVID-19 patients and control subjects at admission

\begin{tabular}{|c|c|c|c|c|c|c|c|c|}
\hline Characteristic & $\begin{array}{l}\text { Control } \\
\text { group, } \\
\text { median }\end{array}$ & $\begin{array}{l}\text { COVID-19 } \\
\text { group, } \\
\text { median }\end{array}$ & p value & $\begin{array}{l}\text { Mild } \\
\text { COVID-19 } \\
\text { patients } \\
\text { group } \\
\text { median }\end{array}$ & $\begin{array}{l}\text { Moderate } \\
\text { COVID-19 } \\
\text { patients } \\
\text { group } \\
\text { median }\end{array}$ & $\begin{array}{l}\text { Severe } \\
\text { COVID-19 } \\
\text { patients } \\
\text { group } \\
\text { median }\end{array}$ & $\begin{array}{l}\text { Critical } \\
\text { COVID-19 } \\
\text { patients } \\
\text { group } \\
\text { median }\end{array}$ & p value \\
\hline $\begin{array}{l}\text { Age (yrs) } \\
\text { (min-max) }\end{array}$ & $58.5(22-82)$ & $61.3(23-94)$ & 0.205 & $57(28-73)$ & $60.5(41-82)$ & $61(23-94)$ & $70.5(35-81)$ & 0.201 \\
\hline Gender & & & 0.531 & & & & & 0.271 \\
\hline Male, n (\%) & $51(55.4 \%)$ & $44(52.3 \%)$ & & $8(47.1 \%)$ & $24(53.3 \%)$ & $12(75 \%)$ & $5(41.7 \%)$ & \\
\hline Female, n (\%) & $41(44.6 \%)$ & $40(47.6 \%)$ & & $9(52.9 \%)$ & $21(46.7 \%)$ & $4(25 \%)$ & $7(58.3 \%)$ & \\
\hline Comorbidity & $41(45.1 \%)$ & $51(54.3 \%)$ & 0.264 & $10(58.8 \%)$ & $22(48.9 \%)$ & $7(43.8 \%)$ & $10(83.3 \%)$ & 0.141 \\
\hline Hypertension & $25(28.4 \%)$ & $33(36.7 \%)$ & & $6(35.3 \%)$ & $14(31.1 \%)$ & $7(43.8 \%)$ & $6(50 \%)$ & 0.598 \\
\hline Diabetes & $18(20.4 \%)$ & $22(24.4 \%)$ & & $4(23.5 \%)$ & $8(17.8 \%)$ & $5(31.3 \%)$ & $5(41.7 \%)$ & 0.331 \\
\hline COPD & $9(10.2 \%)$ & $12(13.3 \%)$ & & $1(5.9 \%)$ & $2(6.7 \%)$ & $3(12.5 \%)$ & $6(50 \%)$ & $0.001^{*}$ \\
\hline $\mathrm{CAD}$ & $9(10.7 \%)$ & $11(12.2 \%)$ & & 0 & $4(8.9 \%)$ & $4(25 \%)$ & $3(25 \%)$ & $0.039^{*}$ \\
\hline $\begin{array}{l}\text { Cerebrovascular } \\
\text { disease }\end{array}$ & $1(1.1 \%)$ & $1(1.1 \%)$ & & - & $1(2.2 \%)$ & 0 & 0 & 0.780 \\
\hline $\begin{array}{l}\text { Chronic kidney } \\
\text { disease }\end{array}$ & $5(5.6 \%)$ & $4(4.4 \%)$ & & $1(5.9 \%)$ & $3(6.7 \%)$ & 0 & 0 & 0.592 \\
\hline Viral hepatitis & - & $1(1.1 \%)$ & & 0 & 0 & 0 & $1(8.3 \%)$ & 0.056 \\
\hline Asthma & $6(6.8 \%)$ & $4(4.4 \%)$ & & 0 & $2(4.4 \%)$ & $1(6.3 \%)$ & $1(8.3 \%)$ & 0.858 \\
\hline \multicolumn{9}{|l|}{ Symptom-sign } \\
\hline Fever & - & $47(51.6 \%)$ & & $7(14.9 \%)$ & $24(51.1 \%)$ & $9(19.1 \%)$ & 7 (14.9\%) & 0.665 \\
\hline Dyspnea & - & $46(50.5 \%)$ & & $6(13 \%)$ & $20(43.5 \%)$ & $11(23.9 \%)$ & $9(19.6 \%)$ & $0.045^{*}$ \\
\hline Cough & - & $42(46.2 \%)$ & & $6(14.3 \%)$ & $23(54 . \% 8)$ & $6(14.3 \%)$ & $7(16.7 \%)$ & 0.418 \\
\hline Weakness & - & $27(29.7 \%)$ & & $8(29.6 \%)$ & $14(51.9 \%)$ & $2(7.4 \%)$ & 3(11.1\%) & 0.230 \\
\hline Sore throat & - & $9(9.9 \%)$ & & $4(44.4 \%)$ & $2(22.2 \%)$ & $2(22.2 \%)$ & $1(11.1 \%)$ & 0.226 \\
\hline Anosmia & - & $5(5.5 \%)$ & & $1(20 \%)$ & $2(40 \%)$ & - & $2(40 \%)$ & 0.271 \\
\hline Diarrhea & - & $11(12.1 \%)$ & & $2(18.2 \%)$ & $4(36.4 \%)$ & $2(18.2 \%)$ & $3(27.3 \%)$ & 0.506 \\
\hline Chest pain & - & $5(5.5 \%)$ & & & $3(60 \%)$ & $1(20 \%)$ & $1(20 \%)$ & 0.372 \\
\hline Headache & - & $4(4.4 \%)$ & & $1(25 \%)$ & $1(25 \%)$ & $2(50 \%)$ & - & 0.306 \\
\hline Joint pain & - & $17(18.7 \%)$ & & $8(47.1 \%)$ & $7(41.2 \%)$ & - & $2(11.8 \%)$ & $0.008^{*}$ \\
\hline
\end{tabular}

* $\mathrm{p}<0.05$ was considered statistically significant; $\mathrm{COPD}=$ chronic obstructive pulmonary disease; $\mathrm{CAD}=$ coronary artery disease

group $(\mathrm{p}<0.05)$. L-lactate dehydrogenase $(\mathrm{LDH})$ values were significantly higher than in healthy controls $(\mathrm{p}<0.05)$; however, RDW-CV levels and PVI were significantly higher in the COVID-19 patient group compared to healthy controls $(\mathrm{p}<0.05)$. Ferritin, C-reactive protein $(\mathrm{CRP})$ and sedimentation acute phase reactants were significantly higher compared to the healthy control group $(\mathrm{p}<0.05)$. As shown in Table 2 , difference in MPV values was not statistically significant $(\mathrm{p}=0.387)$.

\section{Laboratory parameters according to disease severity in COVID-19 patients}

Laboratory parameters of COVID-19 patients divided into 4 groups were compared to investigate the effect of disease severity on blood parameters. Differences in laboratory findings among groups are shown in Table 3. Analysis of the RDW-CV and MPV blood parameters, and PVI (in this study investigated in COVID-19 patients) yielded statistically significant difference according to disease severity $(\mathrm{p}<0.05)$. However, difference in the platelet laboratory param- 
Table 2. Results of laboratory parameters in COVID-19 patients and control group

\begin{tabular}{|l|l|l|l|}
\hline Laboratory parameter & $\begin{array}{l}\text { Control group } \\
(\text { mean } \pm \text { SD })\end{array}$ & $\begin{array}{l}\text { COVID-19 patient group } \\
(\text { mean } \pm \text { SD) }\end{array}$ & p value \\
\hline Red blood cell distribution width-CV (RDW-CV)(\%) & $12.8 \pm 0.7$ & $13.6 \pm 1.3$ & $0.000^{*}$ \\
Mean platelet volume (MPV), fl & $10.3 \pm 0.94$ & $10.1 \pm 1.06$ & 0.387 \\
PVI (MPV/platelet ratio) & $3.2 \pm 1.2$ & $5.7 \pm 2.5$ & $0.000^{*}$ \\
Total protein $(65-85 \mathrm{~g} / \mathrm{L})$ & $73.2 \pm 4.5$ & $69.8 \pm 7.8$ & 0.048 \\
Albumin $(40-55 \mathrm{~g} / \mathrm{L})$ & $46.13 \pm 2.5$ & $39.8 \pm 4.8$ & $0.000^{*}$ \\
LDH, U/L & $172.5 \pm 26$ & $247.6 \pm 55.2$ & $0.000^{*}$ \\
Ferritin, mL/ng & $364.5 \pm 54.4$ & $58.4 \pm 49.9$ & $0.003^{*}$ \\
C-reactive protein $(0-6 \mathrm{mg} / \mathrm{L})$ & $1.5 \pm 0.9$ & $53.12 \pm 10.4$ & $0.010^{*}$ \\
Hemoglobin, g/L & $14.2 \pm 1.2$ & $13.8 \pm 1.8$ & 0.276 \\
Platelet x10 $/ \mathrm{L}$ & $293 \pm 55.2$ & $209.4 \pm 58.3$ & $0.000^{*}$ \\
WBC $\left(4.0-10.0 \times 10^{9} / \mathrm{L}\right)$ & $7.2 \pm 1.3$ & $10.04 \pm 3.8$ & $0.023^{*}$ \\
Neutrophil $\left(2.0-6.0 \times 10^{9} / \mathrm{L}\right)$ & $4.1 \pm 1.23$ & $5.7 \pm 3.5$ & $0.013^{*}$ \\
Lymphocyte $\left(1.1-3.2 \times 10^{9} / \mathrm{L}\right)$ & $2.3 \pm 0.7$ & $1.6 \pm 0.9$ & $0.000^{*}$ \\
\hline
\end{tabular}

$\mathrm{SD}=$ standard deviation; $\mathrm{PVI}=$ platelet volume index $\mathrm{LDH}=\mathrm{L}$-lactate dehydrogenase WBC = white blood count; Mann-Whitney U test was used on statistical analysis; ${ }^{*} \mathrm{p}<0.05$ was considered significant

Table 3. Laboratory parameters according to COVID-19 severity

\begin{tabular}{|l|l|l|l|l|l|}
\hline & $\begin{array}{l}\text { Mild } \\
\text { COVID-19 } \\
\text { group } \\
\text { Laboratory parameter }\end{array}$ & $\begin{array}{l}\text { Moderate } \\
\text { COVID-19 } \\
\text { group } \\
(\text { mean } \pm \text { SD) }\end{array}$ & $\begin{array}{l}\text { Severe } \\
\text { severity } \\
\text { COVID-19 } \\
\text { group } \\
\text { (mean } \pm \text { SD) }\end{array}$ & $\begin{array}{l}\text { Critical } \\
\text { severity } \\
\text { COVID-19 } \\
\text { group } \\
\text { (mean } \pm \text { SD) }\end{array}$ & p value \\
\hline Red blood cell distribution width-CV (\%) & $13.2 \pm 1.9$ & $13.5 \pm 0.8$ & $13.6 \pm 1.19$ & $14.4 \pm 1.16$ & $0.000^{*}$ \\
Mean platelet volume, fl & $9.9 \pm 0.8$ & $10.1 \pm 1.08$ & $10.2 \pm 1.08$ & $10.4 \pm 1.2$ & $0.044^{*}$ \\
PVI & $5.01 \pm 1.8$ & $5.4 \pm 2.04$ & $5.8 \pm 2.02$ & $7.8 \pm 4.4$ & $0.000^{*}$ \\
Total protein $(65-85 \mathrm{~g} / \mathrm{L})$ & $73 \pm 3.3$ & $72.4 \pm 5.5$ & $68.8 \pm 4.21$ & $67.7 \pm 4.8$ & $0.048^{*}$ \\
Albumin $(40-55 \mathrm{~g} / \mathrm{L})$ & $40.8 \pm 3.3$ & $40.2 \pm 4.2$ & $40.1 \pm 4.1$ & $36.2 \pm 3.8$ & $0.000^{*}$ \\
LDH, U/L & $230.4 \pm 70$ & $240.7 \pm 65$ & $264.8 \pm 75$ & $270.4 \pm 85$ & $0.000^{*}$ \\
C-reactive protein $(0-6 \mathrm{mg} / \mathrm{L})$ & $26.8 \pm 4.2$ & $43.7 \pm 7.2$ & $57.7 \pm 6.8$ & $102.5 \pm 20.7$ & $0.010^{*}$ \\
Platelet $\times 10^{9} / \mathrm{L}$ & $219.7 \pm 104$ & $203 \pm 52.6$ & $201.6 \pm 80$ & $200 \pm 68$ & 0.704 \\
WBC $\left(4.0-10.0 \times 10^{9} / \mathrm{L}\right)$ & $7.6 \pm 3.1$ & $7.8 \pm 4$ & $8 \pm 3.5$ & $9.6 \pm 3.8$ & $0.023^{*}$ \\
Neutrophil $\left(2.0-6.0 \times 10^{9} / \mathrm{L}\right)$ & $4.1 \pm 1.23$ & $5.7 \pm 3.5$ & $6.1 \pm 3.3$ & $6.8 \pm 3.9$ & $0.013^{*}$ \\
Lymphocyte & $1.9 \pm 0.8$ & $1.6 \pm 0.9$ & $1.5 \pm 0.6$ & $1.19 \pm 0.8$ & $0.000^{*}$ \\
$\left(1.1-3.2 \times 10^{9} / \mathrm{L}\right)$ &
\end{tabular}

$\mathrm{SD}=$ standard deviation; $\mathrm{LDH}=\mathrm{L}-$ lactate dehydrogenase $; \mathrm{WBC}=$ white blood count; $\mathrm{PVI}$ = platelet volume index; Kruskal-Wallis $\mathrm{H}$ test was used on statistical analysis; ${ }^{\mathrm{p}} \mathrm{p}<0.05$ was considered significant

eter among the disease severity groups was not statistically significant $(p>0.05)$. Correlation between disease severity and laboratory parameters is shown in Table 4. Accordingly, RDW-CV, MPV and PVI values were found to have a moderately positive correlation with disease severity. Evaluation of the patient survival rate showed that $78 \%(n=71)$ of the patients survived and $22 \%(n=20)$ deceased. Analysis of lung images of COVID-19 patients showed involvement of the right upper lobe in $63.2 \%(n=53)$, right middle lobe in $65.5 \%$ 
Table 4. Correlation between disease severity and laboratory parameters

\begin{tabular}{|l|l|l|}
\hline $\begin{array}{l}\text { Laboratory } \\
\text { parameter }\end{array}$ & $\begin{array}{l}\text { Correlation coefficient } \\
\left(\mathrm{r}_{\mathrm{s}}\right)\end{array}$ & $\mathrm{p}$ value \\
\hline RDW-CV & 0.509 & $0.000^{*}$ \\
MPV & 0.383 & $0.028^{*}$ \\
PVI & 0.371 & $0.006^{*}$ \\
\hline
\end{tabular}

Spearman rank correlation method was used on statistical analysis; * $\mathrm{p}<0.05$ was considered significant; RDW-CV = red blood cell distribution width; MPV = mean platelet volume; PVI = platelet volume index

$(\mathrm{n}=57)$, right lower lobe in $77.9 \%(\mathrm{n}=67)$, left upper lobe in $64 \%(n=54)$ and left lower lobe in $86 \%(n=74)$ of the patients.

\section{ROC analysis for $R D W-C V, M P V$ and MPV/Plt parameters}

Laboratory parameters of the COVID-19 patients divided into mild-moderate and severe-critical severity groups according to their clinical findings are shown in Table 5. By dividing COVID-19 patients into two groups of mild-moderate and severe-critical severity, the AUC, cut-off, sensitivity, and specificity of $\mathrm{RDW}-\mathrm{CV}$ and MPV laboratory parameters, and $\mathrm{MPV} / \mathrm{Plt}$ ratio were analyzed with $\mathrm{ROC}$ curve to guide the clinician concerning diagnostic efficacy and follow-up of COVID-19 patients. However, mortality rates, cut-off points, sensitivity and specificity of these laboratory parameters were also analyzed with ROC curve in COVID-19 patients. The cut-off values, AUC, sensitivity and specificity of RDW-CV, MPV and MPV/Plt parameters, which were found to be statistically significant, were determined to be used in distinguishing the clinical pictures of COVID-19 cases and in their follow-up in critical care units. For the RDW-CV parameter, the AUC, cut-off, sensitivity and specificity were $0.734 \%, 13.65 \%, 95 \%$ and $66 \%$, respectively. The AUC, cut-off, sensitivity, specificity of the MPV/Plt ratio were $0.745,0.057,80 \%$ and $65 \%$, respectively. The AUC, cut-off, sensitivity and specificity of the MPV parameter were $0.714 \%, 11.05,55 \%$ and $81 \%$, respectively (Table 6, Fig. 1 ).

The AUC, cut-off, sensitivity and specificity for the $\mathrm{RDW}-\mathrm{CV}$ parameter in predicting mortality were $0.800 \%, 13.75 \%, 89.3 \%$ and $71 \%$, respectively. The AUC, cut-off, sensitivity and specificity of the MPV/Plt

Table 5. Laboratory parameters according to clinical groups of COVID-19 patients

\begin{tabular}{|l|l|l|l|}
\hline Laboratory parameter & $\begin{array}{l}\text { Mild-moderate COVID-19 } \\
\text { group (mean } \pm \text { SD) }\end{array}$ & $\begin{array}{l}\text { Severe-critical COVID-19 } \\
\text { group (mean } \pm \text { SD) }\end{array}$ & p value \\
\hline Red blood cell distribution width-CV $(\%)$ & $13.2 \pm 1.9$ & $13.6 \pm 1.19$ & $0.000^{*}$ \\
Mean platelet volume, $f$ & $9.9 \pm 0.8$ & $10.2 \pm 1.08$ & $0.043^{*}$ \\
PVI & $5.3 \pm 1.9$ & $6.7 \pm 2.3$ & $0.000^{*}$ \\
C-reactive protein $(0-6 \mathrm{mg} / \mathrm{L})$ & $26.8 \pm 4.2$ & $57.7 \pm 6.8$ & $0.010^{*}$ \\
Platelet $x 10^{9} / \mathrm{L}$ & $219.7 \pm 104$ & $201.6 \pm 80$ & $0.000^{*}$ \\
WBC $\left(4.0-10.0 \times 10^{9} / \mathrm{L}\right)$ & $7.8 \pm 3.8$ & $8.79 \pm 3.7$ & $0.023^{*}$ \\
Neutrophil $\left(2.0-6.0 \times 10^{9} / \mathrm{L}\right)$ & $5.5 \pm 3.4$ & $6.4 \pm 3.6$ & $0.013^{*}$ \\
Lymphocyte $\left(1.1-3.2 \times 10^{9} / \mathrm{L}\right)$ & $1.6 \pm 0.7$ & $1.5 \pm 0.7$ & $0.000^{*}$ \\
\hline
\end{tabular}

$\mathrm{SD}=$ standard deviation; $\mathrm{WBC}=$ white blood count; PVI = platelet volume index; Mann-Whitney U test was used on statistical analysis; * $\mathrm{p}<0.05$ was considered significant

Table 6. ROC analysis of laboratory parameters for use in COVID-19 severity monitoring plan

\begin{tabular}{|l|l|l|l|l|l|l|}
\hline $\begin{array}{l}\text { Laboratory } \\
\text { parameter }\end{array}$ & Cut-off value & AUC & p value & $\begin{array}{l}95 \% \text { CI } \\
\text { (lower bound- upper bound) }\end{array}$ & Sensitivity \% & Specificity \% \\
\hline RDW-CV, \% & 13.65 & 0.734 & 0.001 & $0.634-0.834$ & 95 & 66 \\
MPV, fl & 11.05 & 0.711 & 0.004 & $0.538-0.840$ & 55 & 81 \\
PVI & 0.057 & 0.745 & 0.001 & $0.627-0.864$ & 80 & 65 \\
\hline
\end{tabular}

$\mathrm{ROC}=$ receiver operating characteristic curve; $\mathrm{AUC}=$ area under curve; $95 \% \mathrm{CI}=95 \%$ confidence interval; RDW $=$ red cell distribution width $\mathrm{MPV}=$ mean platelet volume $\mathrm{PVI}=$ platelet volume index 
ratio were $0.650,0.057,68 \%$ and $63 \%$, respectively. Although it was found to be statistically significant in predicting mortality, as shown in Table 7 , the specificity

ROC Curve

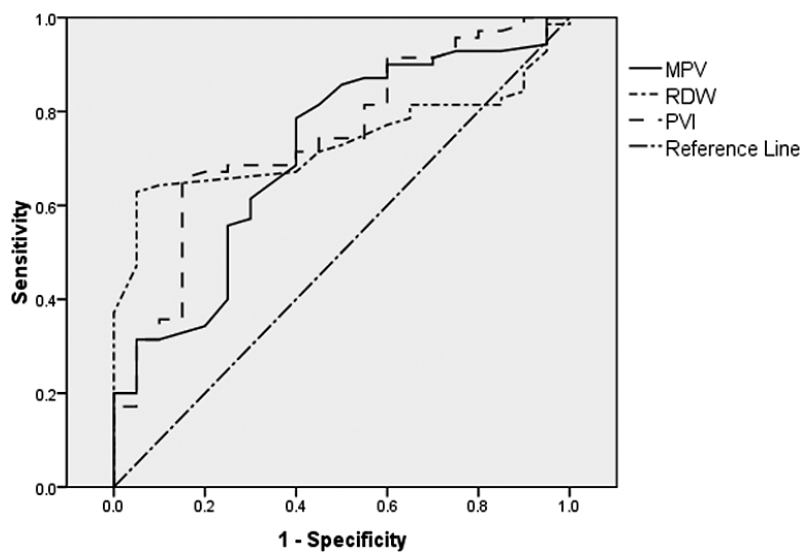

Fig. 1. ROC analysis of laboratory parameters according to clinical groups of COVID-19 patients.

$\mathrm{MPV}=$ mean platelet volume; RDW = red blood cell distribution width; PVI = platelet volume index and sensitivity of the MPV parameter were found to be lower than RDW-CV and MPV/Plt ratio (Fig. 2).

\section{Discussion}

COVID-19 is an acute infectious disease caused by a new coronavirus (SARS-CoV-2) and can progress from mild symptoms such as fever, dry cough, joint pain, and sore throat to a severe picture such as shortness of breath, respiratory failure and multiple organ dysfunction syndrome ${ }^{33}$. However, there also are asymptomatic patients presenting no symptoms. With increase in the number of asymptomatic COVID-19 patients, the potential risk of contagion increases ${ }^{34}$. Early diagnosis of the disease and active and effective treatment plans anticipating and containing exacerbation of the disease can reduce mortality. In the light of constantly updated information on COVID-19, easyto-use, low-cost and widely used laboratory tests are important in determining the severity of the disease. Comparison of hematologic parameters in our study

Table 7. ROC analysis of laboratory parameters to predict mortality

\begin{tabular}{|l|l|l|l|l|l|l|}
\hline $\begin{array}{l}\text { Laboratory } \\
\text { parameter }\end{array}$ & Cut-off value & AUC & p value & $\begin{array}{l}\text { 95\% CI } \\
\text { (lower bound- upper bound) }\end{array}$ & Sensitivity \% & Specificity \% \\
\hline RDW-CV $\%$ & 13.75 & 0.800 & 0.000 & $0.634-0.834$ & 89.3 & 71 \\
MPV, fl & 10.1 & 0.630 & 0.049 & $0.538-0.840$ & 53 & 61 \\
PVI & 0.057 & 0.745 & 0.023 & $0.627-0.864$ & 68 & 63 \\
\hline
\end{tabular}

$\mathrm{ROC}=$ receiver operating characteristic curve; $\mathrm{AUC}=$ area under curve; $95 \% \mathrm{CI}=95 \%$ confidence interval; RDW = red cell distribution width; MPV = mean platelet volume; $\mathrm{PVI}=$ platelet volume index

ROC Curve

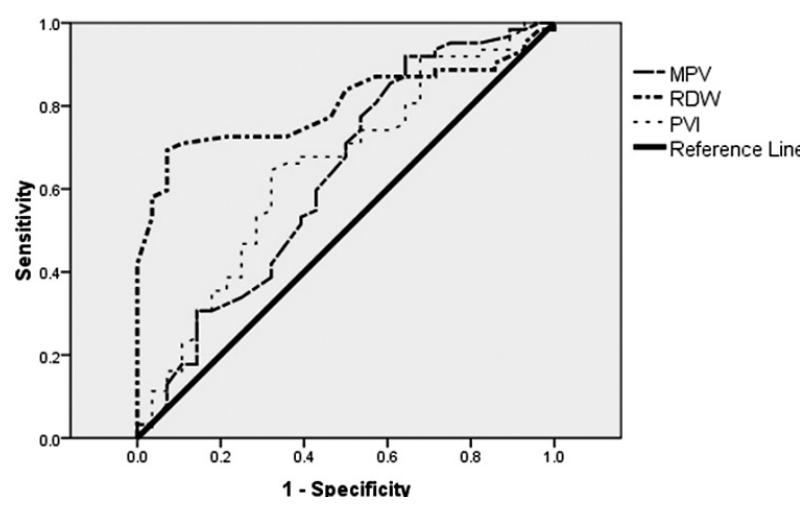

Fig. 2. Laboratory parameters for predicting mortality by $R O C$ analysis.

$\mathrm{MPV}=$ mean platelet volume; $\mathrm{RDW}=$ red blood cell distribution width; PVI = platelet volume index revealed that COVID-19 patient group had significantly higher white blood cell (WBC), neutrophil, $\mathrm{LDH}$, ferritin and CRP values compared to the healthy control group $(\mathrm{p}<0.05)$. However, lymphocytes, platelets, total protein and albumin were significantly lower in COVID-19 patients $(p<0.05)$. These data are consistent with those reported in the literature $^{35-38}$. However, many studies report that lymphopenia is caused by depletion of lymphocytes by the immune system organs after lymphocyte invasion of SARS-CoV-2 $35,36,39,40$.

Evaluation of the RDW-CV laboratory parameter, which was investigated in this study, showed that this parameter was significantly higher in COVID-19 patients as compared with control group. It was also on rise in the critical patient group, and this difference 
was significantly higher among patient groups. Furthermore, our study found that this parameter was significantly higher in COVID-19 patients in terms of predicting mortality. Regarding the $\mathrm{RDW}-\mathrm{CV}$ parameter, when damage to the immune system and suppression of the bone marrow occurs in the human body, compensatory hyperplasia of the erythroid cell line is activated. However, a large number of immature red blood cells are released, which in turn increases the $\mathrm{RDW}$. The RDW-CV laboratory parameter is increased in cases that develop multiorgan failure such as severe sepsis ${ }^{41}$. Similarly, in COVID-19, an increase in the $\mathrm{RDW}-\mathrm{CV}$ laboratory parameter is common due to damage to the immune system. However, Kim et al. report that the RDW parameter was a predictor of mortality during multiorgan failures such as sepsis and septic shock ${ }^{41}$. Considering that COVID-19 may also progress to multiorgan failure, the $\mathrm{RDW}-\mathrm{CV}$ results in our study support those literature reports. Accordingly, we suggest that the RDW-CV parameter may be a predictor of mortality in COVID-19 patients. In their study on COPD patients, Kalemci et al. found that the RDW laboratory parameter increased significantly with the disease severity and development of hypoxemia ${ }^{42}$. The fact that COVID-19 severely affects the lungs and causes hypoxemia in the advanced stages of the disease supports the RDW-CV results in our study.

Platelets are important immune cells that play a role in hemostasis and coagulation, as well as in the immune and inflammatory mechanisms ${ }^{43}$. Differences in platelet count and activity are associated with various diseases ${ }^{44,45}$; in acute respiratory failure, platelets tend to decrease as a result of damage to the lungs ${ }^{46}$. In a study conducted in atypical pneumonia patients, platelets were also decreased ${ }^{47}$. In our study, platelet levels were found to be significantly lower in COVID-19 patients compared to healthy controls. Considering that SARS-CoV-2 causes damage to the lungs, our findings are similar to the low platelet levels reported in the literature. However, another result of this study was that the platelet laboratory parameter did not help us evaluate the severity of the disease. Similarly, Wang et al. in their COVID-19 study report that platelet levels were not effective in evaluating the severity of the disease ${ }^{48}$, which is similar to the findings in our study.
Evaluation of the MPV laboratory parameter, also investigated in this study, showed that there was no difference in MPV values between the healthy control group and COVID-19 patients. Korniluk et al. report that MPV acted as an acute phase reactant in different inflammatory conditions ${ }^{49}$. The increase in the MPV parameter during the inflammatory state is probably associated with increase in the percentage of large platelets due to the intracellular synthesis of pro-coagulatory and pro-inflammatory factors, and degranulation of granules ${ }^{50}$. It has been reported that a change in the MPV laboratory parameter is observed in sepsis and systemic inflammatory response syndrome compared to healthy population ${ }^{51-53}$. This difference between our study and previous studies has emerged because the selected patient population had a more severe clinical course in those studies. Moreover, in our study, difference was found between the groups on evaluating the severity of the MPV parameter, and there was an increasing trend towards the severe patient group. In our study, the fact that the MPV values in severe COVID-19 patients were significant compared to other COVID-19 groups can be useful in predicting disease severity. Two studies in the literature emphasize that the MPV parameter is a biomarker indicating poor prognosis ${ }^{54,55}$. In our study, the significance of the MPV laboratory parameter in the evaluation of mortality may be useful for clinicians in evaluating prognosis. In a study conducted in diabetic COVID-19 patients, it is reported that the MPV value was increased in these patients ${ }^{23}$. In our study, a significant increase was found in the MPV values of COVID-19 patients with comorbidities such as diabetes. If COVID-19 patients have comorbidities in their history, the MPV laboratory parameter may also be beneficial for clinicians in patient observation.

Since COVID-19 is a disease with multiple variables, many studies are still ongoing. In this study, the MPV/Plt ratio was found to be significantly higher in COVID-19 patients compared to healthy population. The importance of PVI in evaluating platelet activation and predicting mortality has been reported in previous studies ${ }^{53,56}$. Similar to our study, Ates et al. found that the MPV/Plt ratio was significantly higher in sepsis patients compared to control group ${ }^{53}$. Fei et al. state that PVI could be beneficial in the diagnosis and differential diagnosis of disease in their study of the influenza virus ${ }^{57}$. This study also found that PVI was 
useful in evaluating disease severity and predicting mortality, as well as diagnosing COVID-19.

To facilitate the clinicians' planning follow up of COVID-19 patients, this study evaluated COVID-19 patients divided into two groups, i.e. a group of patients with serious to critical severity COVID-19 and group of patients with mild to moderate severity $\mathrm{CO}$ VID-19. In addition to the patient group diagnostic guide, the RDW-CV, MPV and MPV/Plt ratio were found to be significantly higher in the serious-critical severity group as compared to the mild-moderate severity group; moreover, when the relationship between the groups was evaluated, moderate correlation was found with these laboratory parameter values. The high sensitivity of RDW-CV and PVI may help clinicians in the assessment of the patient clinical course from the first follow up.

This study had some limitations, including a relatively small sample size and single-center design.

\section{Conclusion}

In conclusion, we think that the RDW-CV laboratory parameter and PVI, which were evaluated within the scope of the study, may be the parameters that should be considered in the early diagnosis of the disease from the initial stages of COVID-19. In addition, we think that the RDW-CV and MPV laboratory parameters, and PVI, which are among the simple, inexpensive and widely used hematologic tests, can be used as important biomarkers in defining the disease severity and evaluating its mortality. We believe that these parameters will facilitate early clinical intervention in COVID-19, thereby contributing to the reduction of patient mortality.

\section{References}

1. WHO Director-General's remarks at the media briefing on 2019-nCoV on 11 February 2020. Available from: https:// www.who.int/dg/speeches/detail/who-director-general-s-remarks-at-the-media-briefing-on-2019-ncov-on-11-February-2020.

2. Huang C,Wang Y, Li X, et al. Clinical features of patients infected with 2019 novel coronavirus in Wuhan, China. Lancet. 2020;395:497-506. https://dx.doi.org/10.1016/S0140-6736 (20)30183-5.

3. Peng Zhou, Xing-Lou Yang, Xian-Guang Wang, et al. A pneumonia outbreak associated with a new coronavirus of probable bat origin. Nature. 2020;579(7798):270-3. https://dx.doi. org/10.1038/s41586-020-2012-7.

4. Li G, Fan Y, Lai Y, Han T, Li Z, Zhou P, et al. Coronavirus infections and immune responses. J Med Virol. 2020;92:42432. https://dx.doi.org/10.1002/jmv.25685.

5. Tang N, Li D, Wang X, Sun Z. Abnormal coagulation parameters are associated with poor prognosis in patients with novel coronavirus pneumonia. J Thromb Haemost. 2020;18:844-7. https://dx.doi.org/10.1111/jth.14768.

6. Llitjos JF, Leclerc M, Chochois C, et al. High incidence of venous thromboembolic events in anticoagulated severe COVID-19 patients. J Thromb Haemost. 2020;18:1743-6. https:// dx.doi.org/10.1111/jth.14869.

7. Klok FA, Kruip MJHA, van der Meer NJM, Arbous MS, Gommers DAMPJ, Kant KM, Kaptein FHJ, van Paassen J, Stals MAM, Huisman MV, Endeman H. Incidence of thrombotic complications in critically ill ICU patients with COVID-19. Thromb Res. 2020;191:145-7. https://dx.doi.org/ 10.1016/j.thromres.2020.04.013.

8. Zhang L, Feng X, Zhang D, Jiang C, Mei H, Wang J, et al. Deep vein thrombosis in hospitalized patients with coronavirus disease 2019 (COVID-19) in Wuhan, China: prevalence, risk factors, and outcome. Circulation. 2020;142(2):114-28.https:// dx.doi.org/10.1161/CIRCULATIONAHA.120.046702.

9. Helms J, Tacquard C, Severac F, Leonard-Lorant I, Ohana M, Delabranche X, et al.; CRICS TRIGGERSEP Group (Clinical Research in Intensive Care and Sepsis Trial Group for Global Evaluation and Research in Sepsis). High risk of thrombosis in patients with severe SARS-CoV-2 infection: a multicenter prospective cohort study. Intensive Care Med. 2020;46(6):1089-98. https://dx.doi.org/10.1007/s00134-02006062-x.

10. Lodigiani C, Iapichino G, Carenzo L, Cecconi M, Ferrazzi P, Sebastian T, et al.; Humanitas COVID-19 Task Force. Venous and arterial thromboembolic complications in COVID-19 patients admitted to an academic hospital in Milan, Italy. Thromb Res. 2020;191:9-14. https://dx.doi.org/10.1016/j.thromres. 2020.04.024.

11. Cui S, Chen S, Li X, Liu S, Wang F. Prevalence of venous thromboembolism in patients with severe novel coronavirus pneumonia. J Thromb Haemost. 2020;18:1421-4. https://dx. doi.org/10.1111/jth.14830.

12. Salvagno GL, Sanchis-Gomar F, Picanza A, Lippi G. Red blood cell distribution width: a simple parameter with multiple clinical applications. Crit Rev Clin Lab Sci. 2015;52(2): 86-105. https://dx.doi.org/10.3109/10408363.2014.992064.

13. Yčas JW, Horrow JC, Horne BD. Persistent increase in red cell size distribution width after acute diseases: a biomarker of hypoxemia? Clin Chim Acta. 2015;448:107-17. https://dx.doi. org/10.1016/j.cca.2015.05.021.

14. Braun E, Domany E, Kenig Y, Mazor Y, Makhoul BF, Azzam ZS. Elevated red cell distribution width predicts poor outcome in young patients with community acquired pneumonia. Crit Care. 2011;15(4):R194. https://dx.doi.org/10.1186/cc10355. 
15. Ozsu S, Abul Y, Gunaydin S, Orem A, Ozlu T. Prognostic value of red cell distribution width in patients with pulmonary embolism. Clin Appl Thromb Hemost. 2014;20(4):365-70. https://dx.doi.org/10.1177/1076029612464901.

16. Versteeg HH, Heemskerk JW, Levi M, Reitsma PH. New fundamentals in hemostasis. Physiol Rev. 2013;93(1):327-58. https://dx.doi.org/10.1152/physrev.00016.2011.

17. Middleton EA, Weyrich AS, Zimmerman GA. Platelets in pulmonary immune responses and inflammatory lung diseases. Physiol Rev. 2016;96(4):1211-59. https://dx.doi.org/10.1152/ physrev.00038.2015.

18. Morrell CN, Aggrey AA, Chapman LM, Modjeski KL. Emerging roles for platelets as immune and inflammatory cells. Blood. 2014;123(18):2759-67. https://dx.doi.org/10.1182/ blood-2013-11-462432.

19. Khurana D, Deoke SA. Thrombocytopenia in critically ill patients: clinical and laboratorial behavior and its correlation with short-term outcome during hospitalization. Indian J Crit Care Med. 2017;21:861-4. https://dx.doi.org/ 10.4103/ijccm.IJCCM_279_17.

20. Vanderschueren S, De Weerdt A, Malbrain M, Vankersschaever D, Frans E, Wilmer A, Bobbaers H. Thrombocytopenia and prognosis in intensive care. Crit Care Med. 2000;28(6):1871-6. https://dx.doi.org/10.1097/00003246-200006000-00031.

21. Hui P, Cook DJ, Lim W, Fraser GA, Arnold DM. The frequency and clinical significance of thrombocytopenia complicating critical illness: a systematic review. Chest. 2011;139 (2):271-8. https://dx.doi.org/10.1378/chest.10-2243.

22. Budak YU, Polat M, Huysal K. The use of platelet indices, plateletcrit, mean platelet volume and platelet distribution width in emergency non-traumatic abdominal surgery: a systematic review. Biochem Med (Zagreb). 2016;26(2):178-93. https://dx.doi.org/10.11613/BM.2016.020.

23. Ozder A. A novel indicator predicts 2019 novel coronavirus infection in subjects with diabetes. Diabetes Res Clin Pract. 2020;166:108294. https://dx.doi.org/10.1016/j.diabres.2020. 108294.

24. Akar T. Can mean platelet volume indicate Helicobacter positivity and severity of gastric inflammation? An original study and review of the literature. Acta Clin Croat. 2019;58(4):576-82. https://dx.doi.org/10.20471/acc.2019.58.04.02.

25. Bae SH, Lee J., Roh KH, Kim J. Platelet activation in patients with diabetic retinopathy. Korean J Ophthalmol. 2003;17 (2):140-4. https://dx.doi.org/10.3341/kjo.2003.17.2.140.

26. Khan HA, Alhomida AS, Sobki SH, Moghairi AA, Koronki HE. Blood cell counts and their correlation with creatine kinase and $\mathrm{C}$-reactive protein in patients with acute myocardial infarction. Int J Clin Exp Med. 2012;5(1):50-5. PMID: 22328948.

27. Sit M, Aktas G, Ozer B, Kocak MZ, Erkus E, Erkol H, Yaman S, Savli H. Mean platelet volume: an overlooked herald of malignant thyroid nodules. Acta Clin Croat. 2019;58(3):417-20. https://dx.doi.org/10.20471/acc.2019.58.03.03.
28. Brummitt DR, Barker HF. The determination of a reference range for new platelet parameters produced by the Bayer ADVIA120 full blood count analyser. Clin Lab Haematol. 2000;22(2):103-7. https://dx.doi.org/10.1046/j.1365-2257. 2000.00285.x.

29. Zaccardi F, Rocca B, Pitocco D, Tanese L, Rizzi A, Ghirlanda G. Platelet mean volume, distribution width, and count in type 2 diabetes, impaired fasting glucose, and metabolic syndrome: a meta-analysis. Diabetes Metab Res Rev. 2015;31(4):402-10. https://dx.doi.org/10.1002/dmrr.2625.

30. Kaplan ZS, Jackson SP. The role of platelets in atherothrombosis. Hematology Am Soc Hematol Educ Program. 2011;2011: 51-61. https://dx.doi.org/10.1182/asheducation-2011.1.51.

31. Halk Saglig1 Genel Mudurlugu. COVID-19 (SARS-CoV-2 Enfeksiyonu) Rehberi. Bilim Kurulu Çalısması. Ankara: Saglık Bakanlıg1.https://covid19bilgi.saglik.gov. tr/depo/rehberler/ COVID-19_Rehberi.pdf.(accessed April 14, 2020).

32. Dündar T, Kitiş S, Abdallah A, Yurtsever İ, Gülen B. Evaluation of the platelet volume index as a prognostic factor after aneurysmal subarachnoid hemorrhage. J Surg Med. 2019;3 (9):685-8. https://dx.doi.org/10.28982/josam.567491.

33. WHO-China Joint Mission, Report of the WHO-China Joint Mission on Coronavirus Disease 2019 (COVID-19), (2020). https://www.who.int/docs/default-source/coronaviruse/whochina-joint-mission-on-covid-19-final-report.pdf (accessed March 1, 2020).

34. Luo SH, Liu W, Liu ZJ, Zheng XY, Hong CX, Liu ZR, Liu J, Weng JP. A confirmed asymptomatic carrier of 2019 novel coronavirus. Chin Med J (Engl). 2020 May 5;133(9):1123-5. https://dx.doi.org/10.1097/CM9.0000000000000798.

35. Shi Q, Zhao K-L, Yu J, et al. Clinical characteristics of 101 non-survivors hospitalized with COVID-19 - a single center, retrospective study. medRxiv. 2020; https://dx.doi.org/10.1101 /2020.03.04.20031039.

36. Tan L, Wang Q, Zhang D, Ding J, Huang Q, Tang YQ, Wang Q, Miao H. Correction: Lymphopenia predicts disease severity of COVID-19: a descriptive and predictive study. Signal Transduct Target Ther. 2020;5:61. https://dx.doi.org/10.1038/ s41392-020-0159-1.

37. Guan WJ, Ni ZY, Hu Y, Liang W, Ou C, He J, et al. Clinical characteristics of 2019 novel coronavirus infection in China. N Engl J Med. 2020;382:1708-20. https://dx.doi.org/10.1056/ NEJMoa2002032.

38. Chen G, Wu D, Guo W, et al. Clinical and immunologic features in severe and moderate forms of coronavirus disease 2019. J Clin Invest. 2020;130(5):2620-9. https://dx.doi.org/10.1172/ JCI137244.

39. Chen N, Zhou M, Dong X, Qu J, Gong F, Han Y, et al. Epidemiological and clinical characteristics of 99 cases of 2019 novel coronavirus pneumonia in Wuhan, China: a descriptive study. Lancet. 2020;395(10223):507-13. https://dx.doi.org/10.1016/ S0140-6736(20)30211-7.

40. Huang C, Wang Y, Li X, Ren L, Zhao J, Hu Y, et al. Clinical features of patients infected with 2019 novel coronavirus in 
Wuhan, China. Lancet. 2020;395(10223):497-506. https:// dx.doi.org/10.1016/S0140-6736(20)30183-5.

41. Kim CH, Park JT, Kim EJ, Han JH, Han JS, Choi JY, et al. An increase in red blood cell distribution width from baseline predicts mortality in patients with severe sepsis or septic shock. Crit Care. 2013 Dec 9;17(6):R282. https://dx.doi.org/10.1186/ cc13145.

42. Kalemci S, Akin F, Sarihan A, et al. The relationship between hematological parameters and the severity level of chronic obstructive lung disease. Pol Arch Intern Med. 2018;128(3): 171-7. https://dx.doi.org/10.20452/pamw.4198.

43. Hvas AM. Platelet function in thrombosis and hemostasis. Semin Thromb Hemost. 2016 Apr;42(3):183-4. https://dx.doi. org/10.1055/s-0036-1572329.

44. Jenne CN, Kubes P. Platelets in inflammation and infection. Platelets. 2015;26(4):286-92. https://dx.doi.org/10.3109/0953 7104.2015.1010441.

45. Güneş M, Büyükgöl H. Relationship between generalized epileptic seizure and neutrophil/lymphocyte ratio, platelet/lymphocyte ratio, and neutrophil mediated inflammation. Int J Neurosci. 2020;130(11):1095-100. https://dx.doi.org/10.1080/ 00207454.2020 .1722662 .

46. Poon TC, Pang RT, Chan KC, Lee NL, Chiu RW, Tong YK, Chim SS, Ngai SM, Sung JJ, Lo YM. Proteomic analysis reveals platelet factor 4 and beta-thromboglobulin as prognostic markers in severe acute respiratory syndrome. Electrophoresis. 2012 Jul;33(12):1894-900. https://dx.doi.org/10.1002/elps. 201200002.

47. Sun DH, Qiu YR, Zeng FY, et al. Blood routine characteristics of 96 cases of infectious atypical pneumonia in Guangzhou. J First Mil Med Univ. 2005;25:1333-4.

48. Wang C, Deng R, Gou L, Fu Z, Zhang X, Shao F, et al. Preliminary study to identify severe from moderate cases of COVID-19 using combined hematology parameters. Ann Transl Med. 2020 May;8(9):593. https://dx.doi.org/10.21037/atm20-3391.

49. Korniluk A, Koper-Lenkiewicz OM, Kamińska J, Kemona H, Dymicka-Piekarska V.Mean platelet volume (MPV): new perspectives for an old marker in the course and prognosis of inflammatory conditions. Mediators Inflamm. 2019 Apr 17; 2019:9213074. https://dx.doi.org/10.1155/2019/9213074.
50. Schwertz H, Köster S, Kahr WH, Michetti N, Kraemer BF, Weitz DA, Blaylock RC, Kraiss LW, Greinacher A, Zimmerman GA, Weyrich AS. Anucleate platelets generate progeny. Blood. 2010 May 6;115(18):3801-9. https://dx.doi.org/ 10.1182/blood-2009-08-239558.

51. Kim CH, Kim SJ, Lee MJ, Kwon YE, Kim YL, Park KS, Ryu HJ, Park JT, Han SH, Yoo TH, Kang SW, Oh HJ. An increase in mean platelet volume from baseline is associated with mortality in patients with severe sepsis or septic shock. PLoS One. 2015 Mar 5;10(3):e0119437. https://dx.doi.org/10.1371/journal.pone.0119437.

52. Kitazawa T, Yoshino Y, Tatsuno K, Ota Y, Yotsuyanagi H. Changes in the mean platelet volume levels after bloodstream infection have prognostic value. Intern Med. 2013;52(13):148793. https://dx.doi.org/10.2169/internalmedicine.52.9555.

53. Ates S, Oksuz H, Dogu B, Bozkus F, Ucmak H, Yanit F. Can mean platelet volume and mean platelet volume/platelet count ratio be used as a diagnostic marker for sepsis and systemic inflammatory response syndrome? Saudi Med J. 2015 Oct;36(10):1186-90. https://dx.doi.org/10.15537/smj.2015. 10.10718.

54. Lee JH, Park M, Han S, Hwang JJ, Park SH, Park SY. An increase in mean platelet volume during admission can predict the prognoses of patients with pneumonia in the intensive care unit: a retrospective study. PLoS One. 2018 Dec 11;13(12): e0208715. https://dx.doi.org/10.1371/journal.pone.0208715.

55. Gorelik O, Tzur I, Barchel D, Almoznino-Sarafian D, Swarka $\mathrm{M}$, Beberashvili I, et al. A rise in mean platelet volume during hospitalization for community-acquired pneumonia predicts poor prognosis: a retrospective observational cohort study. BMC Pulm Med. 2017;17(1):137. https://dx.doi.org/10.1186/ s12890-017-0483-6.

56. Azab B, Torbey E, Singh J, Akerman M, Khoueiry G, McGinn JT, Widmann WD, Lafferty J. Mean platelet volume/platelet count ratio as a predictor of long-term mortality after non-STelevation myocardial infarction. Platelets. 2011;22(8):557-66. https://dx.doi.org/10.3109/09537104.2011.584086.

57. FeiY,Zhang H,Zhang C.The application oflymphocyte*platelet and mean platelet volume/platelet ratio in influenza $\mathrm{A}$ infection in children. J Clin Lab Anal. 2019 Nov;33(9):e22995. https://dx.doi.org/10.1002/jcla.22995. 


\section{Sažetak \\ PROCJENA ODNOSA SREDNJEG VOLUMENA TROMBOCITA, ŠIRINE DISTRIBUCIJE ERITROCITA I INDEKSA VOLUMENA TROMBOCITA S TEŽINOM BOLESTI KOD BOLESNIKA S COVID-19}

\section{Atik i H.B. Kaya}

Koronavirus je prvi put otkriven kod tri slučaja teške upale pluća u Wuhanu, Kina u prosincu 2019. godine. Istraživanja laboratorijskih parametara širine distribucije eritrocita (RDW-CV) i srednjeg volumena trombocita (MPV) koji se mogu testirati unutar kompletne krvne slike kod bolesnika s COVID-19 još uvijek su vrlo ograničena. Međutim, prema našim saznanjima, nema istraživanja koja bi se bavila odnosom indeksa volumena trombocita (PVI) i težine bolesti kod ovih bolesnika, a upravo to smo ispitivali u našem istraživanju. Cilj studije bio je procijeniti odnos težine bolesti u bolesnika s COVID-19 s parametrima MPV, RDW i PVI. Istraživanje je obuhvatilo 92 bolesnika s COVID-19 i 84 zdrave osobe kao kontrolna skupina. Svi laboratorijski podaci i radiološke snimke preslikane su retrospektivno iz bolesničkih kartona i bolničkog informacijskog sustava. Procjena krvnih parametara RDW-CV i MPV, kao i PVI izmjerenih u bolesnika s COVID-19 pokazala je statistički značajne razlike prema težini bolesti. Predlažemo da bi RDW-CV i PVI koji su istraživani u ovoj studiji mogli poslužiti kao parametri u ranoj dijagnostici bolesti već u početnom stadiju COVID-19. Uz to, smatramo da bi se laboratorijski parametri RDW-CV i MPV te PVI kao jednostavne, jeftine i široko primjenjivane hematološke pretrage mogli primijeniti kao važni biološki biljezi u utvrđivanju težine i smrtnosti COVID-19.

Ključne riječi: COVID-19; Težina bolesti; Srednji volumen trombocita; Širina distribucije eritrocita; Indeks volumena trombocita 